\title{
PENGARUH GENDER, RELIGIOSITAS, DAN KECERDASAN INTELEKTUAL MAHASISWA TERHADAP PERILAKU ETIS AKUNTAN MASA DEPAN
}

\author{
Arianto $^{1)}$, Rahman Sastrawan ${ }^{2)}$, \& Nia Pratiwi ${ }^{3)}$ \\ 1, 2,3 Jurusan Akuntansi, Politeknik Negeri Pontianak, Indonesia \\ 1 email: arianto@mail.polnep.ac.id \\ 2 email: namanyarahmansastrawan@gmail.com \\ 3 email: pratiwinia19@gmail.com
}

\begin{abstract}
This research aims to analyze the influence of gender, religiosity, and intellectual intelligence on ethical behavior in the future. These influences will be able to cause the progress of an accounting profession whether to be good or even vice versa to be bad. The research methodology used in this study is a method with a level of clarity (explanatory) and the type of research is quantitative by conducting surveys and distributing questionnaires to respondents namely accounting students as future accountants. After the respondent fills in the questionnaire, the data will be processed presented in the form of a Likert scale. The results of this study indicate that future accountants can be trusted if they have a good ethical attitude. This research is useful to serve as a presentation of teaching materials for business and professional ethics courses.
\end{abstract}

Keywords: Gender, Religiosity, Intellectual Intelligence, and Ethical Behavior.

\section{PENDAHULUAN}

Permasalahan etika dalam akuntansi berawal dari munculnya skandal keuangan dunia yang dilakukan oleh Enron Corporation dengan Kantor Akuntan Publik (KAP) Andersen yang terungkap pada akhir tahun 2001. Skandal keuangan dunia yang lainnya seperti kasus Health South pada tahun 2003, kasus AIG pada tahun 2005, kasus Subprime Loans pada tahun 2007, kasus WordCOm dan kasus Global Crossing di Amerika pada tahun 2010, kasus skandal keuangan yang pernah terjadi di Indonesia yaitu kasus PT. kimia Farma pada tahun 2010 dan PT. Bumi Resources tahun 2010 (Suryana, 2002). Kasus etika yang terbaru terjadi di Indonesia adalah PT Garuda Indonesia pada tahun 2018.

Munculnya permasalahan etika dalam bidang akuntansi berdampak tentang keyakinan publik terhadap profesi akuntan. Permasalahan yang kadang terjadi pada akuntan berkaitan dengan praktik pelanggaran moral, terjadinya praktik pelanggaran moral tersebut biasanya dilakukan oleh akuntan manajemen, akuntan publik, maupun akuntan pemerintahan. Perilaku etis akuntan harus ditanamkan semenjak sumber daya manusia memasuki dunia pendidikan. Perilaku etis akuntan akan berdampak kepada publik sebagai jasa pengguna profesi akuntan.

Dunia pendidikan sangat penting untuk ditingkatkan, karena kualitas pendidikan akan menentukan sumber daya manusia pada periode berikutnya (Junusi, 2020). Pendidikan yang bermoral dan etis sangat penting dalam tatanan bermasyarakat. Perilaku pada pemimpim di masa yang akan datang dapat dilihat pada perilaku mahasiswa 
sekarang (Reiss dan Mitra, 1998). Perilakuperilaku pada mahasiswa sangat penting untuk diteliti agar dapat mengetahui sejauh mana mereka akan berperilaku etis atau tidak dimasa depan berikutnya.

Carr et al., (1977) menyatakan bahwa perempuan lebih cenderung memperlihatkan kepedulianya lebih besar dari pada pria, dan wanita lebih mungkin menyadari dan peka tehadap masalah etika. Berarti perilaku etis mempunyai hubungan dengan gender yang dapat merubah perubahan pada perilaku manusia.

Menurut Glock dan Stark dalam Pamungkas, (2014) menyatakan bahwa religiositas merupakan suatu sistem yang selalu terintegrasi pada keyakinan (belief), aktivitas, gaya hidup dan institusi yang memberikan suatu makna pada kehidupan manusia dan mengarahkan nilai tertinggi atau nilai-nilai suci. Hasil penelitian menunjukkan bahwa gender dan religiositas berpengaruh secara siqnifikan terhadap perilaku etis. Perilaku etis tidak hanya dinilai dari gender dan religiositas saja, melainkan dapat juga dinilai dari pendidikan yaitu kecerdasan intelektual. Kecerdasan intelektual adalah kemampuan untuk mengarahkan tindakan dan pikiran, sehingga suatu individu mampu berpikir rasional, selain itu kecerdasan intelektual dapat muncul dari kesadaran mahasiswa akuntansi tersebut.

Masalah pada penelitian ini dirumuskan sebagai berikut. Pertama menganalisis pengaruh gender terhadap perilaku etis akuntan masa depan (mahasiswa akuntansi Politeknik Negeri Pontianak dan Politeknik Negeri Pontianak di Sanggau). Kedua menganalisis pengaruh religiositas terhadap perilaku etis akuntan masa depan (mahasiswa akuntansi Politeknik Negeri Pontianak dan Politeknik Negeri Pontianak di Sanggau). Ketiga menganalisis pengaruh kecerdasan intelektual terhadap perilaku etis akuntan masa depan (mahasiswa akuntansi Politeknik Negeri Pontianak dan Politeknik
Negeri Pontianak di Sanggau). Manfaat dari penelitian ini adalah memberikan referensi sebagai pengayaan bahan ajar mata kuliah etika bisnis dan profesi serta memberikan dampak yang positif bagi publik dan akuntan masa depan.

\section{TINJAUAN PUSTAKA}

\subsection{Teori Etika}

Etika adalah paham yang meletakkan tujuan sebagai ukuran suatu perbuatan atau perilaku manusia. Menurut Agoes, Sukrisno and Ardana (2013) ada lima teori etika yaitu teori teologi, teori deontologi, teori hak, teori keutamaan (virtue theory), dan teori teonom.

Teori teologi adalah paham yang meletakkan tujuan sebagai ukuran suatu perbuatan. Etika teologi mempunyai dua paham aliran yaitu egoisme dan utilitarisme. Ajaran egoisme berpendapat bahwa perbuatan dari setiap seseorang pada intinya untuk memajukan dirinya sendiri, sedangkan pandangan utilitarisme berpendapat bahwa suatu perbuatan atau tindakan dilihat dari kuantitas kebaikan, tindakan yang baik akan menghasilkan manfaat yang terbesar.

Teori deontologi adalah suatu perbuatan dinilai dari ukuran baik buruknya suatu perbuatan pada kewajiban. Perbuatan dinilai baik karena perbuatan itu bernilai pada diri sendiri, bukan karena tercapainya keinginan sendiri.

Pendekatan teori hak pada dasarnya banyak digunakan untuk menilai buruk baiknya suatu perilaku atau perbuatan. Aspek dari teori deontology adalah gambaran dari teori hak, karena berhubungan dengan kewajiban. Kewajiban dan hak biasanya diibaratkan seperti uang logam yang mempunyai dua sisi. Pada saat sekarang ini hak banyak ditonjolkan daripada kewajiban, padahal teori terdahulu mengutamakan kewajiban baru mendapatkan hak. 
Teori keutamaan (virtue) adalah suatu kencenderungan watak seseorang untuk menetukan sikap. Sikap seseorang diperoleh dengan cara kebiasaan dirinya, sehingga memungkinkan orang untuk bertingkah baik laku secara moral.

Teori teonom berpendapat bahwa sifat moral manusia secara mutlak adalah tunduk dengan perintah Tuhan Yang Maha Esa. Teori teonom bertujuan untuk memperoleh kebahagian surgawi, karena perilaku atau perbuatan mengarah suatu kebaikan.

\subsection{Etika Bisnis dan Profesi}

Menurut Muslich (2004) etika bisnis dapat diartikan sebagai pemahaman tata cara pengaturan dan pengelolaan bisnis yang selalu memperhatikan moralitas dan norma yang berlaku secara umum dan secara sosial/ekonomi. Etika profesi merupakan suatu sikap etis dari bagian kesempurnaan sikap hidup dalam melaksanakan kehidupan sebagai pengemban profesi. Profesi dalam bidang akuntansi biasa disebut akuntan, seseorang akuntan profesional haruslah menjalankan kode etik profesi.

Kode etik prinsip-prinsip dasar akuntan menurut Ikatan Akuntan Indonesia (IAI) adalah tanggung jawab profesi, integritas, kepentingan publik, obyektivitas, kompetensi dan kehati-hatian profesional, kerahasiaan, perilaku professional, dan standar teknis. Tujuan kode etik profesi akuntansi antara lain: (1) meningkatkan mutu profesi, (2) menjunjung tinggi martabat profesi, (3) meningkatkan pengabdian anggota profesi, (4) meningkatkan layanan di atas keuntungan pribadi, (5) menjaga dan memelihara kesejahteraan para anggota, (6) adanya organisasi professional yang kuat dan terjalin erat, dan (7) menentukan standar baku.

\subsection{Gender}

Jenis kelamin (sex) merupakan kata lain dari gender, sedangkan Menurut (Asrini
(2013) menegaskan bahwa sex berbeda dengan gender, walaupun secara etimologis artinya gender sama dengan sex, yaitu jenis kelamin. Gender sering dianggap juga sebagai kodrat Ilahi atau pemberian Tuhan. Studi sex memusatkan kepada perkembangan aspek biologis dan komposisi kimia pada tubuh seseorang pria dan seseorang perempuan, dimana studi tersebut memusatkan kepada sifat fiminim dan maskulinitas seseorang. Padahal perbedaan gender antara seorang pria dan wanita muncul melalui proses yang sangat lama, terbentuknya perbedaan tersebut disebabkan oleh faktor-faktor seperti, kondisi keagamaan, kondisi sosial budaya, dan kondisi kenegaraan.

\subsection{Religiositas}

Religiositas merupakan hubungan manusia dengan sang pencipta melalui ajaran agama atau keyakinan yang sudah dihayati dalam diri seseorang dan tergambarkan dalam kehidupan sehari-hari. Religiositas menurut Majid (1997) adalah perbuatan manusia yang sepenuhnya dibentuk oleh keyakinan kepada alam gaib ke dalam hati dan sikap personal.

Menurut Aviyah \& Farid (2014) religiositas adalah merupakan suatu aspek yang telah terinternalisasi oleh individu di dalam hati, serta getaran hati nurani pribadi dan sikap personal. Pada hakekatnya religiositas mempunyai nilai tinggi yang dimiliki oleh seseorang untuk menjadi insan beragama yang sesungguhnya.

\subsection{Kecerdasan Intelektual}

Kecerdasan secara universal dapat diartikan suatu kemampuan yang dimiliki oleh seseorang, kadang kualitas kecerdasan seseorang yang satu dengan yang lainya dapat berbeda-beda. Kecerdasan Intelektual (IQ) menurut Ifa Hanifah (2008) adalah suatu kempetensi kecerdasan seseorang dalam menuntaskan suatu masalah matematis dan rasional.

Pengaruh Gender, Religiusitas, dan Kecerdasan Intelektual Mahasiswa terhadap Perilaku Etis Akuntan 


\subsection{Perilaku Etis}

Menurut Ika (2011) bahwa perilaku dapat diartikan sebagai reaksi seseorang terhadap suatu objek yang merupakan kontelasi kognitif, konatif, dan afektif yang disebabkan oleh suatu motivasi yang menghendaki adanya respon (pendirian). Menurut Griffin dan Ebert dalam Maryani dan Ludigdo (2001) bahwa perilaku etis merupakan perilaku yang sesuai dengan norma-norma sosial yang diterima secara umum sehubungan dengan adanya tindakantindakan yang membahayakan dan bermanfaat.

Berdasarkan dari beberapa pengertian tersebut, perilaku etis mahasiswa akuntansi adalah sikap atau respon mahasiswa akuntansi terhadap suatu kejadian yang mengandung situasi rumit berdasarkan etika profesi akuntansi, baik dalam berpraktek sebagai akuntan manajemen, maupun sebagai akuntan publik.

\subsection{Kajian Empiris}

Publik mengharapkan kepada akuntan masa depan memiliki sikap perilaku etis yang baik, kepercayaan yang besar terhadap akuntan saat ini dipertanyakan oleh publik, maka dari itu seorang akuntan harus memiliki nilai-nilai etis yang tinggi. Penelitian ini merujuk pada beberapa penelitian terdahulu sebagai referensi.

Penelitian yang dilakukan Febrianty (2010) tentang pengaruh gender, locus of control, intellectual capital, dan ethical sensitivity terhadap perliaku etis mahasiswa akuntansi pada perguruan tinggi, menunjukkan bahwa variabel gender berpengaruh terhadap perilaku etis, variabel locus of control tidak berpengaruh terhadap perilaku etis mahasiswa akuntasi pada perguruan tinggi, sedangkan variabel ethical sensitivity dan intellectual capital berpengaruh positif dan signifikan terhadap perilaku etis mahasiswa akuntansi pada perguruan tinggi.
Wardana \& Mimba (2016) melakukan penelitian tentang kecerdasan intelektual, kecerdasan emosional, kecerdasan spiritual, dan gender pada sikap etis mahasiswa magister akuntansi Universitas Udayana. Variabel bebasnya adalah kecerdasan intelektual, kecerdasan emosional, kecerdasan spiritual, dan gender, sedangkan vaiabel terikatnya adalah sikap etis. Hasil dari penelitian ini dapat disimpulkan bahwa variabel kecerdasan emosional, kecerdasan intelektual, kecerdasan spiritual berpengaruh terhadap sikap etis, sedangkan variabel gender tidak berpengaruh terhadap sikap etis.

Ridha Oktarina (2017) melakukan penelitian tentang pengaruh gender terhadap perilaku etis akuntan di Minangkabau. Variabel bebas dari penelitian ini adalah gender, sedangkan variabel terikatnya adalah perilaku etis akuntan di Minangkabau. Hasil dari penelitian ini dapat disimpulkan bahwa gender laki-laki dan perempuan hasilnya bias terhadap perilaku etis akuntan di Minangkabau.

Azmi (2017) melakukan penelitian tentang pengaruh gender, religiositas, prestasi belajar mahasiswa, dan muatan etika dalam pengajaran akuntansi terhadap perilaku etis akuntan masa depan. Variabel independen yang digunakan adalah gender, religiositas, prestasi belajar dan muatan etika, sedangkan variabel dependennya adalah perilaku etis akuntan masa depan. Hasil dari penelitian ini ditemukan bukti-bukti empiris bahwa gender tidak berpengaruh signifikan terhadap perilaku etis akuntan masa depan, sedangkan religiositas, prestasi belajar dan muatan etika berpengaruh signifikan terhadap perilaku etis akuntan masa depan.

\subsection{Kerangka Konseptual}

Berdasarkan uraian di atas yaitu pada latar belakang, tinjauan pustaka dan landasan-landasan teori, maka dapat 
disimpulkan kerangka konseptual pada penelitian ini adalah sebagai berikut:

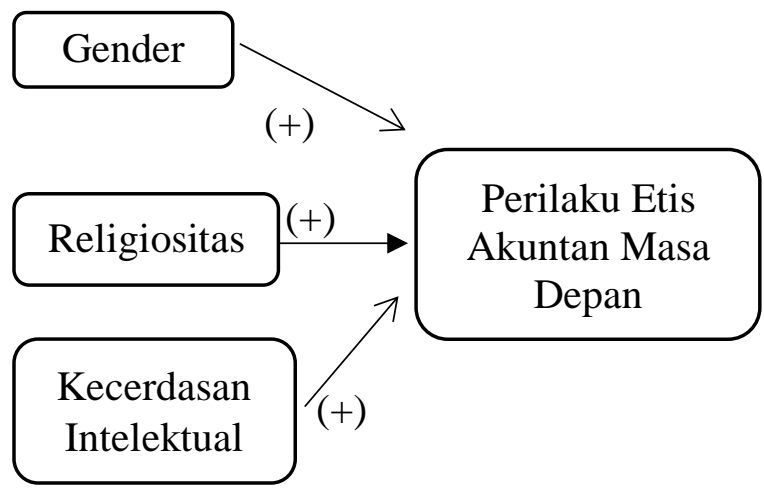

\section{Gambar 1. Kerangka Konseptual Penelitian}

\subsection{Hipotesis Penelitian}

Berdasarkan pada landasan teori dan penelitian terdahulu, serta kerangka konseptual tentang faktor-faktor yang berpengaruh terhadap perilaku etis akuntan masa depan, maka hipotesi penelitian yang dapat dijelaskan sebagai berikut:

1) Pengaruh Gender Mahasiswa terhadap Perilaku Etis Akuntan Masa Depan (Studi Pada Mahasiswa Akuntansi Polnep dan Polnep Sanggau)

Dilihat dari sudut pandang sosial di masyarakat bahwa pria dan wanita memiliki nilai yang berbeda dalam melakukan suatu pekerjaan. Pria bersaing dalam mencapai kesuksesan cenderung melanggar peraturan pekerjaan, sedangkan wanita tidak dalam melakukan tugas. Menurut Carr et al dalam Azmi (2017) menegaskan bahwa sex berbeda dengan gender, meskipun secara etimologis artinya gender sama dengan sex, yaitu jenis kelamin. Adapun perbedaan yang lain antara pria dan wanita adalah dilihat dari proses pengambilan keputusan. Dengan demikian, dapat disajikan hipotesis sebagai berikut:

H1: Gender berpengaruh positif terhadap perilaku etis akuntan masa depan
2) Pengaruh Religiositas Mahasiswa terhadap Perilaku Etis Akuntan Masa Depan (Studi Pada Mahasiswa Akuntansi Polnep dan Polnep Sanggau)

Religiositas merupakan suatu perbuatan atau tindakan seseorang atau individu untuk melaksanakan ajaran-ajaran agama. Menurut Hasan dalam Muhlis (2011) bahwa Ajaran agama yang telah yakini dapat menjadi pendorong kehidupan individu dalam berinteraksi dengan Tuhan dan sesama manusia. Agama atau keyakinan akan menjadikan perilaku manusia menjadi lebih baik. Keyakinan seseorang mempunyai peranan penting dalam mengambil keputusan etis, karena nilai-nilai dan standar pribadi yang sering berhubungan dengan latar belakang agama seseorang. Dengan demikian, dapat disajikan hipotesis sebagai berikut:

H2: Religiositas berpengaruf positif terhadap perilaku etis akuntan masa depan

3) Pengaruh Kecerdasan Intelektual Mahasiswa terhadap Perilaku Etis Akuntan Masa Depan (Studi Pada Mahasiswa Akuntansi Polnep dan Polnep Sanggau)

Perilaku atau perbuatan seseorang bisa mempengaruhi kecerdasan intelektual, sehingga nilai-nilai etis harus dimiliki oleh mahasiswa akuntansi untuk menjadi akuntan masa depan. Menurut Tikollah, dkk (2006) menyatakan bahwa pandangan suatu kelompok yang menenkankan kecerdasan intelektual sebagai kemampuan aklimatisasi, serta orang yang cerdas akan memiliki kemampuan untuk mengorganisasi pola-pola tingkah laku sehingga dapat bertindak lebih tepat dan efektif. Dengan demikian, dapat disajikan hipotesis sebagai berikut:

H3: Kecerdasan intelektual berpengaruh positif terhadap perilaku etis akuntan masa depan 


\section{METODE PENELITIAN}

Bentuk penelitian yang akan digunakan untuk menganalisis penelitian mengenai "Pengaruh Gender, Religiositas, dan Kecerdasan Intelektual Mahasiswa terhadap Perilaku Etis Akuntan Masa Depan (Studi Pada Mahasiswa Akuntansi Polnep dan Polnep Sanggau)" adalah merupakan jenis penelitian tingkat eksplanari (tingkat kejelasan), dikarenakan penelitian ini bertujuan untuk menjelaskan hubungan kausal antara variabel-variabel dengan meniti pengujian hipotesis yang telah dirumuskan sebelumnya. Pengujian penelitian ini menggunakan program SPSS versi 19.

Penelitian ini akan dilakukan di Politeknik Negeri Pontianak dan Politek Negeri Pontianak di Kabupaten Sanggau pada bulan Agustus dan November 2019. Penelitian pada mahasiswa akuntansi Polnep dan Polnep Sanggau berdasarkan apakah gender, religiositas dan kecerdasan intelektual dapat mempengaruhi perilaku etis akuntan masa depan. Sumber data yang akan digunakan dalam penelitian ini adalah data primer, data primer diperoleh dengan menggunakan daftar pertanyaan kuesinoer yang telah terstruktur dengan tujuan untuk mengumpulkan informasi dari mahasiswa akuntansi Polnep dan Polnep Sanggau sebagai responden pada penelitian ini.

Kuesioner yang disebarkan pada penelitian ini terdiri dari empat bagian, yaitu bagian pertama berisikan beberapa pertanyaan yang berhubungan dengan gender, bagian kedua berisikan beberapa pertanyaan yang berhubungan dengan religiositas, bagian ketiga berisikan sejumlah beberapa pertanyaan yang berhubungan dengan kecerdasan intelektual, dan bagian keempat berisikan beberapa pertanyaan yang berhubungan dengan perilaku etis akuntan masa depan mahasiswa akuntansi. Kuesioner disebarkan disertai dengan surat permohonan serta penjelasan tentang tujuan penelitian yang dilakukan. Petunjuk pengisian jelas dan sesederhana mungkin untuk memudahkan pengisian jawaban sesungguhnya dan lengkap. Pembagian kuesioner diberikan langsung oleh peneliti tanpa perantara pihak lain.

Populasi dalam penelitian ini adalah seluruh mahasiswa akuntansi semester III Polnep dan PSDKU Polnep Sanggau, meningat banyaknya mahasiswa di Politeknik Negeri Pontianak dan Polnep Sanggau, maka responden pada penelitian ini mengambil sampel mahasiswa akuntansi semester III sebanyak 120. Penyebaran kuesioner dilakukan pada mahasiswa akuntansi semester tiga saja.

Variabel dalam penelitian ini terdiri dari variabel bebas $(\mathrm{X})$ dan variabel terikat (Y), adapun variabel terikat (Y) yang digunakan adalah perilaku etis akuntan masa depan yaitu mahasiswa akuntansi Polnep dan PSDKU Polnep Sanggau, sedangkan variabel bebasnya terdiri dari gender mahasiswa (X1), religiositas mahasiswa (X2), dan kecerdasan intelektual mahasiswa (X3). Pengukuran penelitian pada variabel gender mahasiswa adalah menggunakan skala likert melalui pertanyaan yang terdapat dalam kuesioner. Pertanyaan dalam kuesioner yaitu terdiri dari atas, Sangat Setuju (SS) dengan nilai 5, Setuju (S) dengan nilai 4, Netral (N) dengan nilai 3, Tidak Setuju (TS) dengan nilai 2, Sangat Tidak Setuju (STS) dengan nilai 1. Kuesioner yang akan digunakan pada penelitian ini mengadopsi dengan modifikasi (Azmi, 2017).

Pengukuran penelitian pada variabel religiositas juga menggunakan skala likert melalui pertanyaan yang terdapat dalam kuesioner. Pertanyaan dalam kuesioner yaitu terdiri dari atas, Sangat Setuju (SS), dengan nilai 5, Setuju (S) dengan nilai 4, Netral (N) dengan nilai 3, Tidak Setuju (TS) dengan nilai 2, Sangat Tidak Setuju (STS) dengan nilai 1. Kuesioner yang digunakan pada 
penelitian ini mengadopsi dengan modifikasi (Azmi, 2017).

Pengukuran penelitian pada variabel kecerdasan intelektual mahasiswa adalah menggunakan skala likert melalui pertanyaan yang terdapat dalam kuesioner. Pertanyaan dalam kuesioner yaitu terdiri dari atas, Sangat Setuju (SS) dengan nilai 5, Setuju (S) dengan nilai 4, Netral (N) dengan nilai 3, Tidak Setuju (TS) dengan nilai 2, Sangat Tidak Setuju (STS) dengan nilai 1. Kuesioner yang digunakan pada penelitian ini diolah sendiri. Pengukuran penelitian pada variabel perilaku etis akuntan masa depan adalah menggunakan skala likert melalui pertanyaan yang terdapat dalam kuesioner. Pertanyaan dalam kuesioner yaitu terdiri dari atas, Sangat Setuju (SS) dengan nilai 5, Setuju (S) dengan nilai 4, Netral (N) dengan nilai 3, Tidak Setuju (TS) dengan nilai 2, Sangat Tidak Setuju (STS) dengan nilai 1. Kuesioner yang digunakan pada penelitian ini mengadopsi dengan modifikasi (Azmi, 2017).

\subsection{Metode Analisis}

Metode analisis pada yang digunakan dalam penelitian ini adalah statistik deskriptif, uji asumsi klasik dan uji kualitas data. Statistik deskriptif adalah merupakan metode statistika yang digunakan untuk memberikan penjelasan tentang data yang dikumpulkan. Data tersebut meliputi: umur, jenis kelamin, pendidikan, dan lamanya bekerja. Alat analisis untuk uji data ini disajikan dengan menggunakan tabel distribusi deskriptif statistik dan tabel distribusi frekuensi yang memaparkan kriteria standar deviasi, nilai rata-rata, minimum, dan maskimum.

Uji kualitas data pada penelitian ini ditentukan oleh kualitas instrumen yang akan digunakan untuk mengumpulkan data. Instrumen yang valid adalah merupakan alat ukur yang digunakan untuk mendapatkan data yang valid, serta dapat digunakan untuk mengukur apa yang hendak diukur. Data yang kurang valid akan menghasilkan penelitian yang bias, sehingga diperlukan uji kualitas data agar hasilnya valid. Ada dua alat analisis untuk mengukur kualitas data yaitu: uji validitas dan reliabilitas. Uji validitas digunakan untuk mengukur valid tidaknya suatu kuesioner. Kuesioner dikatakan valid jika mempunyai gerakan yang kuat terhadap skor total. Dengan demikian, sebuah item pertanyaan dikatakan mempunyai validitas jika memiliki tingkat korelasi yang tinggi terhadap skor total item. Dua syarat yang harus dipenuhi agar item kuesioner dikatakan valid yaitu:

1. Korelasi dari item-item kuesioner haruslah kuat dan terjadinya peluang kesalahan tidak terlalu besar (menurut teori maksimal 5\% dalam ujian pertama).

2. Korelasi harus memiliki nilai atau arah yang positif, arah positif tersebut berarti (nilai korelasi yang akan digunakan untuk mengukur validitas) harus lebih besar dari $\mathbf{r}$ table.

Uji validitas biasanya menggunakan skala likert dengan menggunakan alat bantu program aplikasi SPSS versi 19.

Tabel 1. Skala Likert

\begin{tabular}{lc}
\hline \multicolumn{1}{c}{ Jawaban } & Nilai \\
\hline STS -Sangat Tidak & 1 \\
Setuju & \\
TS - Tidak Setuju & 2 \\
N -Netral & 3 \\
S - Setuju & 4 \\
SS - Sangat Setuju & 5 \\
\hline Sumber: Amirin (2010)
\end{tabular}

Uji reliabilitas yang digunakan untuk mengukur apakah jawaban responden terhadap kuesioner adalah konsisten atau stabil dari waktu ke waktu (Ghozali, 2011). Suatu konstruk atau variabel dikatakan reliabel jika memberikan nilai Cronbach's Alpha > 0.70 (Nunnally dalam Ghozali 2011). 
Uji asumsi klasik dilakukan sebelum data dianalisis regeresi berganda, adapun uji asumsi klasik terdiri dari: uji normalitas, uji heteroskedastisitas, dan uji multikolinieritas. Uji normalitas digunakan untuk menguji apakah pada model regresi, variabel dependen dan independen keduanya mempunyai distribusi normal atau tidak (Ghozali, 2016). Bentuk regresi yang baik adalah memiliki distribusi data yang normal atau mendekati normal. Uji normalitas data tersebut dapat dilakukan melalui 3 cara yaitu menggunakan uji Kolmogorof-Smirnov (Uji $\mathrm{K}-\mathrm{S}$ ), grafik histogram dan kurva penyebaran P-plot. Untuk Uji K-S yakni jika nilai hasil Uji K-S > dibandingkan taraf signifikansi 0,05 maka sebaran data tidak menyimpang dari kurva normalnya disebut uji normalitas. Sedangkan melalui pola penyebaran P-Plot dan grafik histogram, jika pola penyebaran memiliki garis normal maka data dikatakan berdistribusi normal.

Uji multikolinieritas dilakukan untuk melihat gejala korelasi antara variabel bebas yang satu dengan variabel bebas lainnya. Pada bentuk regresi yang baik seharusnya tidak terdapat hubungan di antara variabel bebas. Uji multikolinieritas dapat dilakukan dengan 2 cara yaitu dengan melihat VIF (Variance Iflastion Factors) dan nilai toleran. Jika nilai toleran $>0,10$ dan VIF $<10$, maka tidak terjadi gejala multikolinieritas (Ghozali, 2016).

Uji ini bertujuan untuk menguji apakah bentuk regresi terjadi ketidaksamaan varian dari residual satu pengamatan ke pengamatan yang lain tetap, atau disebut homoskedastisitas. Model regresi yang baik adalah homoskedastisitas, tidak heteroskedastisitas.

Heteroskedastisitas ditandai dengan adanya pola tertentu pada grafik scatterplot. Jika titik-titik yang ada membentuk suatu pola tertentu yang teratur (begelombang), maka terjadi heteroskedastitsitas. Jika tidak ada pola yang jelas, titik-titik menyebar di atas dan di bawah angka nol pada sumbu Y, maka tidak terjadi heteroskedastisitas.

Selain itu, heteroskedastisitas dapat diketahui uji glesjer. Jika propibilitas signifikansi masing-masing varibel bebas > 0,05, maka dapat disimpulkan tidak terjadi heteroskedastisitas pada bentuk regresi (Ghozali, 2016).

\subsection{Uji Hipotesis}

Uji hipotesis dilaksanakan dengan menggunakan analisis regresi berganda, tujuannya adalah untuk memprediksi seberapa besar kekuatan pengaruh variabel bebas terhadap variabel terikat.

Persamaan regeresinya sebagai berikut:

$$
Y=\alpha+\beta_{1} . X_{1}+\beta_{2} . X_{2}+\beta_{3} X_{3}+\epsilon
$$

\section{Dimana:}

$$
\begin{aligned}
& Y=\text { perilaku etis akuntan masa depan } \\
& \alpha=\text { konstanta } \\
& \beta_{1}, \beta_{2}, \beta_{3}=\text { koefisien regresi } \\
& X_{1}=\text { gender } \\
& X_{2}=\text { religiositas } \\
& X_{3}=\text { kecerdasan intelektual } \\
& \in=\text { nilai residu }
\end{aligned}
$$

\section{HASIL PENELITIAN DAN PEMBAHASAN}

\subsection{Data Penelitian}

Penelitian ini menggunakan data primer yang diperoleh dengan menggunakan daftar pertanyaan (kuesioner). Kuesioner yang dibagikan langsung oleh peneliti dan dibantu mahasiwa Politeknik Negeri Pontianak, kuesioner yang dibagikan kepada mahasiswa Politeknik Negeri Pontianak pada tanggal 27 Oktober 2019 sampai dengan batas waktu 8 November 2019.

kuesioner yang disebarkan berjumlah 183, kueisoner yang kembali sebanyak 181, kuesioner tidak lengkap sebanyak 41, kuesioner lengkap sebanyak 140, dan kuesioner tidak dikembalikan sebanyak 2 . Tingkat pengembalian (response rate) yang diperoleh adalah sebesar 98,91\%, kuesioner 
tidak lengkap sebesar 22,40\%, kuesioner yang digunakan sebesar $76,50 \%$, sedangkan sisanya sebesar $1,43 \%$.

\subsection{Statistik Deskriptif}

Hasil dari uji statistik deskriptif dalam penelitian ini bisa dilihat pada Tabel 2, semua item penelitian mempunyai nilai mean lebih besar dari standar deviasi, sehingga dapat disimpulkan bahwa data yang digunakan valid dan layak.

\section{Tabel 2. Hasil Ouput Uji Statistik} Deskriptif

\begin{tabular}{lccc}
\hline & N & Minimum & M \\
\hline Perilaku Etis & 140 & 36,00 & \\
Gender & 140 & 1 & 1 \\
Religiositas & 140 & 23,00 & \\
Kecerdasan Intelektual & 140 & 27,00 & \\
Valid N & 140 & & \\
\hline
\end{tabular}

\subsection{Uji Normalitas}

Uji normalitas mempunyai tujuan untuk menguji pada model regresi, variabel terikat dan variabel bebas keduanya harus mempunyai ditribusi normal atau tidak. Uji normalitas data pada penelitian ini menggunakan Uji Kolmologrov-Smirnov (Uji K-S), adapun ringkasan analisis bisa dilihat pada Tabel 3 berikut ini.

Tabel 3. Hasil Output Statistik Uji Normalitas

\begin{tabular}{|c|c|}
\hline & $\begin{array}{c}\text { Unstandardized } \\
\text { Residual }\end{array}$ \\
\hline $\mathrm{N}$ & 140 \\
\hline Parameters ${ }^{\mathrm{a}, \mathrm{b}}$ & .0000000 \\
\hline Mean & 4. 29064468 \\
\hline Std. Deviation & \\
\hline $\begin{array}{l}\text { Most Extreme Differences } \\
\text { Absolute }\end{array}$ & .052 \\
\hline & .048 \\
\hline Positif & -.052 \\
\hline $\begin{array}{l}\text { Negatif } \\
\text { Kolmogorov-Smirnov Z } \\
\text { Asymp. Sig. (2-tailed) }\end{array}$ & $\begin{array}{l}.618 \\
.839\end{array}$ \\
\hline
\end{tabular}

Hasil dari uji normalitas pada Tabel 3 di atas menunjukan bahwa nilai KS sebesar 0,618 , nilai ini dapat kita lihat tidak signifikan pada 0,05 (karena nilai signifikan $=0,839$ lebih besar dari 0,05). Dengan demikian, hal ini dapat menjelaskan gambaran bahwa sebaran data tidak menunjukan penyimpangan kurva normalnya, berarti sebaran data telah memenuhi syarat asumsi normalitas.

\subsection{Uji Multikolinieritas}

Uji multikolinieritas dilakukan untuk

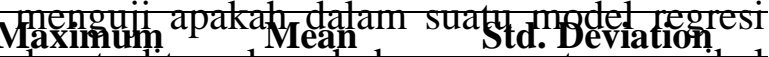

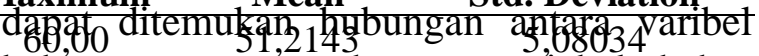
bebas yang satt, 2 dengan varjabget bebas

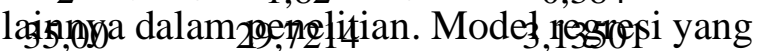

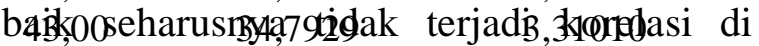
antara variabel bebas. Ada tidak korelasi antar variabel tersebut bisa dideteksi dengan melihat nilai tolerance $>0,10$ dan VIF $<10$, maka dinyatakan tidak ada terjadi multikolinieritas antar variabel independen dan sebaliknya (Ghozali, 2011). Hasil uji multikolinieritas dapat dilihat Tabel 4.

Tabel 4. Hasil Output Statistik Uji Multikolinieritas

\begin{tabular}{lccc}
\hline $\begin{array}{c}\text { Variabel } \\
\text { Bebas }\end{array}$ & \multicolumn{2}{c}{ Collinearity Statistics } & Keputusan \\
& Tolerance & VIF & \\
\hline Gender & 0,982 & 1,019 & $\begin{array}{c}\text { Tidak ada } \\
\text { multikonier } \\
\text { itas }\end{array}$ \\
Religiositas & 0,854 & 1,171 & $\begin{array}{c}\text { Tidak ada } \\
\text { multikonier } \\
\text { itas }\end{array}$ \\
$\begin{array}{l}\text { Kecerdasan } \\
\text { Intelektual }\end{array}$ & 0,867 & 1,153 & $\begin{array}{c}\text { Tidak ada } \\
\text { multikonier } \\
\text { itas }\end{array}$ \\
\hline
\end{tabular}

Berdasarkan hasil out put SPSS di atas bahwa hasil perhitungan nilai Tolerance menunjukan tidak ada variabel bebas yang memiliki nilai Tolerance $<0,10$ yang berarti

Pengaruh Gender, Religiusitas, dan Kecerdasan Intelektual Mahasiswa terhadap Perilaku Etis Akuntan 
bahwa tidak ada hubungan antar variabel bebas yang nilainya lebih dari $95 \%$. Sementara itu, hasil perhitungan nilai Variance Inflation Factor (VIF) juga menunjukan hal yang sama tidak ada satupun variabel bebas yang memiliki nilai VIF $>10$. Dengan demikian, dapat disimpulkan dalam model regresi tidak terjadi multikolinearitas antar variabel independen tersebut.

\subsection{Uji Heteroskedastisitas}

Uji heteroskedastisitas dilakukan untuk menguji apakah dalam suatu model regresi ada terjadi ketidaksamaan varian dari residual pada suatu pengamatan kepengamatan yang lainnya. Jika varian dari residual mempunyai pengamatan tetap pada pengamatan lainnya, maka disebut homoskedastisitas dan sebaliknya jika berbeda disebut heteroskedastisitas. Uji heteroskedastisitas bisa dilakukan dengan menggunakan metode grafik plot Regression Standarized Predicted Value dengan Regression Studentized Residual dan uji glejser. Berdasarkan hasil out put grafik scatterplot tampak sebaran data membentuk pola yang jelas. Hal ini menunjukkan bahwa tidak ada terjadi heteroskedastisitas pada model regresi ini.

Analisis dengan grafik plot memiliki kelemahan, dikarenakan jumlah pengamatan mempengaruhi hasil ploting, untuk lebih meyakinkan keakuratan hasil perlu di uji lagi yaitu dengan uji statistik berupa uji glejser. Hasil uji yang ditampilkan pada Tabel 5 dibawah ini menunjukan bahwa tidak ada satu variabel bebas yang signifikan secara statistik mempengaruhi variabel terikat nilai Absolut Ut (AbsUt). Hal ini terlihat dari probabilitas signifikan di atas tingkat kepercayaan 5\%. Jadi dapat disimpulkan model regresi tidak mengandung adanya heteroskedastisitas.
Tabel 5. Hasil Ouput Statistik Uji Glejser

\begin{tabular}{|c|c|c|c|c|c|}
\hline & $\begin{array}{l}\text { Unstar } \\
\text { d Coef }\end{array}$ & $\begin{array}{l}\text { dardize } \\
\text { icients }\end{array}$ & $\begin{array}{c}\text { Standar } \\
\text { dized } \\
\text { Coeffic } \\
\text { ients }\end{array}$ & & \\
\hline Model & B & $\begin{array}{l}\text { Std. } \\
\text { Error }\end{array}$ & Beta & $\mathrm{t}$ & Sig. \\
\hline (Constant) & 8.969 & 2.608 & & 3.439 & .001 \\
\hline Gender & .741 & .534 & .116 & 1.387 & .168 \\
\hline $\begin{array}{l}\text { Religiosit } \\
\text { as }\end{array}$ & -.083 & .070 & -.106 & $1.178^{-}$ & .241 \\
\hline $\begin{array}{l}\text { Kecerdas } \\
\text { anIntelekt } \\
\text { ual }\end{array}$ & -.125 & .066 & -.169 & 1.895 & .060 \\
\hline
\end{tabular}

\subsection{Uji Validitas}

Jika R-hitung > R-tabel, maka item pada tiap-tiap pertanyaan valid, dan sebaliknya, jika R-hitung < R-tabel, maka item pada tiap-tiap pertanyaan tidak valid.

Berdasarkan Tabel 6 hasil uji validitas instrumen untuk semua butir pertanyaan valid, dikarenakan R-tabel untuk signifikan 0,01 sebesar 0,217, sehingga Rhitung > R-tabel.

\section{Tabel 6. Hasil Output Statistik Uji} Validitas Instrumen

\begin{tabular}{ccccc}
\hline $\begin{array}{c}\text { No } \\
\text { Item }\end{array}$ & \multicolumn{3}{c}{ Koefisien Korelasi Butir } & Keterangan \\
& $\begin{array}{c}\text { Total } \\
\text { Religi } \\
\text { ositas }\end{array}$ & $\begin{array}{c}\text { Kecer } \\
\text { dasan } \\
\text { Intele } \\
\text { ktual }\end{array}$ & $\begin{array}{c}\text { Perilak } \\
\text { u Etis }\end{array}$ & \\
& & & \\
& & & & \\
\hline 1 & 0,599 & 0,612 & 0,639 & Valid \\
2 & 0,727 & 0,597 & 0,676 & Valid \\
3 & 0,556 & 0,502 & 0,730 & Valid \\
4 & 0,658 & 0,427 & 0,732 & Valid \\
5 & 0,555 & 0,564 & 0,247 & Valid \\
6 & 0,657 & 0,570 & 0,685 & Valid \\
7 & 0,688 & 0,520 & 0,734 & Valid \\
8 & - & 0,610 & 0,563 & Valid \\
9 & - & 0,487 & 0,566 & Valid \\
10 & - & - & 0,756 & Valid \\
11 & - & - & 0,743 & Valid \\
12 & - & - & 0,613 & Valid \\
\hline
\end{tabular}




\subsection{Uji Realibilitas}

Uji realibilitas pada penelitian ini menggunakan uji pengukuran sekali aja (one shot) dan hasilnya dibandingkan antar pertanyaan lainnya, dengan kata lain mengukur hubungan antar jawaban pertanyaan dan pengujian ini menggunakan program SPSS versi 19. Hasil dari perhitungan uji statistik realibilitas memperlihatkan bahwa nilai Cronbach's Alpha (a) untuk masing-masing variabel adalah lebih besar dari 0,70, sehingga dapat disimpulkan bahwa item instrumen untuk masing-masing variabel adalah realibel (Ghozali, 2011). Hasil dari uji realibilitas secara terperinci dapat dilihat pada Tabel 7 berikut ini.

Tabel 7. Hasil Output Statistik Uji Reabilitas

\begin{tabular}{lcc}
\hline Variabel & $\begin{array}{c}\text { Cronbach's Alpha } \\
\text { Based on } \\
\text { Standardized Items }\end{array}$ & $\begin{array}{c}\mathrm{N} \text { of } \\
\text { Items }\end{array}$ \\
\hline Religiositas & 0,740 & 7 \\
Kecerdasan & 0,703 & 9 \\
$\begin{array}{l}\text { Intelektual } \\
\text { Perilaku Etis }\end{array}$ & 0,858 & 12 \\
\hline
\end{tabular}

\subsection{Hasil Uji Hipotesis}

Setelah uji asumsi klasik dilakukan dan hasilnya secara menyeluruh

12 an model regresi telah memenuhi sik, maka tahap selanjutnya adalah melaksanakan interprestasi dan evaluasi model regresi berganda. Model regresi berganda pada penelitian ini dilakukan untuk menguji pengaruh variabel bebas Gender (X1), Religiositas (X2), dan Kecerdasan Intelektual (X3) terhadap variabel terikat perilaku etis akuntan masa depan (Y).

Untuk mengetahui hasil pengujian regresi berganda dengan pengujian menggunakan aplikasi SPSS versi 19 dalam bentuk output model summary, ANOVA (uji F), serta coefficient (uji t) dapat dilihat uraikan dibawah ini:

1) Uji Koefisien Determinasi
Berdasarkan tampilan output model summary pada Tabel 8 besarnya nilai koefisien determinasi atau R Square adalah sebesar 0,287 atau sama dengan 28,7\%. Nilai ini menujukan bahwa variabel gender, religiositas, dan kecerdasan intelektual berpengaruh sebesar $28,7 \%$ terhadap perilaku etis, sedangkan $71,3 \%$ sebab lain diluar model. Dapat disimpulkan bahwa semakin rendah nilai koefisien determinasi ( $R$ Square), maka pengaruh variabel bebas terhadap variabel terikat lemah.

\section{Tabel 8. Hasil Uji Koefisien Determinasi}

\begin{tabular}{ccccc}
\hline Model & $\mathbf{R}$ & $\begin{array}{c}\mathbf{R} \\
\text { Square }\end{array}$ & $\begin{array}{c}\text { Adjusted } \\
\mathbf{R} \\
\text { Square }\end{array}$ & $\begin{array}{c}\text { Stnd. } \\
\text { Error }\end{array}$ \\
\hline 1 & 0,535 & 0,287 & 0,271 & 4,33771 \\
\hline
\end{tabular}

2) Uji Parsial (Uji t)

Hasil dari pengujian hipotesi pertama (H1) menyebutkan bahwa variabel gender berpengaruh positif terhadap perilaku etis akuntan masa depan (mahasiswa akuntansi Politeknik Negeri Pontianak dan Program Studi Di Luar Kampus Utama Politeknik Negeri Pontianak Di Kabupaten Sanggau). Pada Tabel 9 dapat dilihat nilai signifikansi (Sig) variabel gender adalah sebesar 0,084, sehingga nilai signifikasi $0,084>$ probabilitas 0,005, dapat disimpulkan bahwa variabel gender (X1) berpengaruh terhadap perilaku etis, tetapi pengaruh tersebut tidak signifikan.

Hasil pengujian ini dipertegas dari hasil perhitungan $t_{\text {hitung }}$ dan $t_{\text {tabel}}$, nilai $t_{\text {tabel }}$ dengan taraf signifikan $5 \%$ dan derajat kebebasan (df) n-k-1 =136 adalah 1,978, jadi $t_{\text {hitung }} 1,740<t_{\text {tabel }} 1,978$, sehingga perubahan atau variasi variabel gender tidak bisa diikuti oleh variabel perilaku etis. Berdasarkan dari hasil pengujian $\mathrm{H} 1$ dapat diinterpretasikan bahwa variabel gender berpengaruh tidak signifikan terhadap perilaku etis akuntan masa depan, dengan kata lain $\mathrm{H} 1$ ditolak.

Pengaruh Gender, Religiusitas, dan Kecerdasan Intelektual Mahasiswa terhadap Perilaku Etis Akuntan Masa Depan 
Tabel 9. Hasil Uji Parsial

\begin{tabular}{|c|c|c|c|c|c|}
\hline $\begin{array}{c}\text { Mode } \\
\text { l }\end{array}$ & Unsta & $\begin{array}{l}\text { lardiz } \\
\text { cients }\end{array}$ & $\begin{array}{l}\text { Stand } \\
\text { ardiz } \\
\text { ed } \\
\text { Coeff } \\
\text { icient } \\
\text { s } \\
\text { Beta }\end{array}$ & $\mathbf{t}$ & g \\
\hline $\begin{array}{c}\text { (Cons } \\
\text { tant) }\end{array}$ & $\begin{array}{r}22,14 \\
1\end{array}$ & 4,716 & & 4,694 & 0,000 \\
\hline $\begin{array}{l}\text { Gend } \\
\text { er }\end{array}$ & 1,681 & 0,966 & 0,127 & 1,740 & 0,084 \\
\hline $\begin{array}{l}\text { Religi } \\
\text { ositas }\end{array}$ & 0,096 & 0,127 & 0,059 & $\begin{array}{r}- \\
0,756\end{array}$ & 0,451 \\
\hline $\begin{array}{l}\text { Kecer } \\
\text { dasan } \\
\text { Intele } \\
\text { ktual }\end{array}$ & $\begin{array}{r}0,83 \\
0\end{array}$ & $\begin{array}{r}0,11 \\
9\end{array}$ & $\begin{array}{r}0,54 \\
1\end{array}$ & $\begin{array}{r}6,95 \\
2\end{array}$ & $\begin{array}{r}0,00 \\
0\end{array}$ \\
\hline
\end{tabular}

Hasil pengujian pada hipotesis kedua (H2) menyebutkan bahwa bahwa variabel religiositas berpengaruh positif terhadap perilaku etis akuntan masa depan (mahasiswa akuntansi Politeknik Negeri Pontianak dan Program Studi Di Luar Kampus Utama Politeknik Negeri Pontianak Di Kabupaten Sanggau). Pada Tabel 9 dapat dilihat nilai signifikansi (Sig) variabel religiositas adalah sebesar 0,451, sehingga nilai signifikasi $0,451>$ probabilitas 0,005, dapat disimpulkan bahwa variabel religiositas (X2) berpengaruh terhadap perilaku etis, tetapi pengaruh tersebut tidak signifikan.

Hasil pengujian ini dipertegas dari hasil perhitungan $t_{\text {hitung }}$ dan $t_{\text {tabel }}$ dengan taraf signifikan 5\% dan derajat kebebasan (df) n$\mathrm{k}-1=136$ adalah 1,978 , jadi $\mathrm{t}_{\text {hitung }} 0,756<\mathrm{t}_{\text {tabel }}$ 1,978, sehingga perubahan atau variasi variabel religiositas tidak akan diikuti oleh variabel perilaku etis. Dilihat dari hasil pengujian $\mathrm{H} 2$ dapat diinterpretasikan bahwa variabel religiositas berpengaruh tidak signifikan terhadap perilaku etis akuntan masa depan, dengan kata lain $\mathrm{H} 2$ ditolak. Hasil dari pengujian hipotesis ketiga menyebutkan bahwa variabel kecerdasan intelektual berpengaruh positif terhadap perilaku etis akuntan masa depan (mahasiswa akuntansi Politeknik Negeri Pontianak dan Program Studi di Luar Kampus Utama Politeknik Negeri Pontianak Di Kabupaten Sanggau). Pada Tabel 9 dilihat signifikansi (sig) variabel kecerdasan intelektual adalah sebesar 0,000, sehingga nilai signifikansi $0,000<$ probabilitas 0,005 , dapat disimpulkan bahwa variabel kecerdasan intelektual (X3) berpengaruh terhadap perilaku etis.

Hasil pengujian ini dipertegas dari hasil perhitungan $t_{\text {hitung }}$ dan $t_{\text {tabel }}$ dengan taraf signifikan $5 \%$ dan derajat kebebasan (df) n$\mathrm{k}-1=136$ adalah 1,978, jadi $\mathrm{t}_{\text {hitung }}>\mathrm{t}_{\text {tabel }}$ 1,978, sehingga perubahan atau variasi variabel kecerdasan intelektual tidak akan diikuti oleh variabel perilaku etis. Dilihat dari hasil pengujian $\mathrm{H} 3$ dapat diinterpretasikan bahwa variabel kecerdasan intelektual berpengaruh signifikan terhadap perilaku etis akuntan masa depan, dengan kata lain H3 diterima.

\subsection{Pembahasan}

Penelitian ini bertujuan untuk menguji pengaruh gender, religiositas, dan kecerdasan intelektual terhadap perilaku etias akuntan masa depan (mahasiswa akuntansi Politeknik Negeri Pontianak dan PSDKU Polnep Sanggau). Secara menyeluruh, hasil dari pengujian hipotesis dengan menggunakan regresi berganda dapat dilihat pada Tabel 10 dibawah ini.

\begin{tabular}{clc}
\multicolumn{2}{c}{ Tabel 10. Ringkasan Hasil Pengujian } \\
Hipotesis
\end{tabular}


$\mathrm{H} 2$

Religiositas berpengaruh positif terhadap perilaku etis

H3

Kecerdasan Intelektual berpengaruh positif terhadap perilaku etis

1) Pengaruh Gender Terhadap Perilaku Etis

Hipotes pertama menyatakan bahwa gender berpengaruh positif terhadap perilau etis. Hasil dari pengujian statistik menunjukkan bahwa nilai signifikansi (Sig) gender sebesar 0,084. Nilai ini menjelaskan bahwa varibel gender tidak signifikan pada tingkat propabilitas 0,05 . Hasil pengujian ini didukung oleh hasil perhitungan $t_{\text {hitung }} 1,740$ $<t_{\text {tabel }} 1,978$. Hal ini menunjukkan bahwa gender berpengaruh tidak signifikan terhadap perilaku etis.

Hasil dari pengujian ini tidak sejalan dengan penelitian Febrianty (2010) bahwa gender berpengaruh signifikan terhadap perilaku etis, tetapi hasil pengujian ini sejalan dengan penelitian Wardana dan Mimba (2016) bahwa gender tidak berpengaruh terhadap perilaku etis. Hal ini menunjukan bahwa wanita dan pria bisa saja sama dalam hal memiliki kelebihan dan kekurangan dalam penalaran perilaku etis, tetapi tidak sedikit pula dari mereka yang sama-sama bersaing pada bidang karir untuk mencari jabatan kekuasan, bahkan mencarai kekayaan yang mereka inginkan tanpa memikirkan pelanggaran etika didalamnya.

2) Pengaruh Religiositas Terhadap

Perilaku Etis

Hipotesi kedua menyatakan bahwa religiositas berpengaruh positif terhadap perilaku etis. Hasil dari pengujian statistik menunjukan bahwa nilai signifikansi (Sig) religiositas sebesar 0,451 , nilai ini menjelaskan bahwa variabel religiositas tidak signifikan pada tingkat probabilitas 0,05. Hasil pengujian ini didukung oleh hasil perhitungan $t_{\text {hitung }} 0,756<t_{\text {tabel }} 1,978$. Hal ini menunjukkan bahwa religiositas berpengaruh tidak signifikan terhadap perilaku etis.

Hasil pengujian ini tidak searah dengan penelitian Azmi (2017) bahwa religiositas berpengaruh terhadap perilaku etis. Tidak sejalannya penelitian ini bukan dikarenakan religiositas yang rendah, namun terdapat faktor-faktor lain yang mempengaruhi antara lain: pertanyaan yang digunakan tidak sama, data yang digunakan jumlahnya berbeda, waktu penelitian berbeda dan tempat penelitian berbeda. Jika seseorang memiliki religiositas yang rendah, maka untuk melaksanakan tugas bisa saja dapat melakukan kecurangan, sebaliknya jika religiositas seseorang tinggi, maka tugas yang dilakukan kemungkinan bebas dari kecurangan.

\section{3) Pengaruh Kecerdasan Intelektual} Terhadap Perilaku Etis

Hipotesis ketiga menyatakan bahwa kecerdasan intelektual berpengaruh positif terhadap perilaku etis. Hasil dari pengujian statistik menunjukan bahwa nilai signifikansi (Sig) sebesar 0,000, nilai ini menjelaskan bahwa variabel kecerdasan intelektual signfikan pada probabilitas 0,05. Hasil pengujian ini didukung oleh hasil perhitungan nilai $t_{\text {hitung }} 6,952>t_{\text {tabel }} 1,978$. Hal ini menunjukkan bahwa kecerdasan intelektual berpengaruh signifikan terhadap perilaku etis.

Hasil pengujian ini sejalan dengan penelitian Wardana dan Mimba (2016) menyatakan bahwa kecerdasan intelektual berpengaruh terhadap perilaku etis secara parsial. Salah satu faktor yang mempengaruhi perilaku etis seseorang adalah lingkungan, dimana sikap dan perilaku etis didapat dari lingkungan pendidikan. Lingkungan pendidikan dapat membentuk seseorang mahasiwa peka tehadap terhadap persoalan etika, dikarena kemampuan berpikirnya. 


\section{SIMPULAN}

Penelitian ini bertujuan untuk mengetahui pengaruh gender, religiositas, dan kecerdasan intelektual terhadap perilaku etis akuntan masa depan (mahasiswa akuntansi Polnep dan PSDKU Polnep Sanggau). Berdasarkan hasil penelitian maka dapat diambil kesimpulan sebagai berikut. Pertama, gender berpengaruh tidak signifikan terhadap perilaku etis akuntan masa depan, sehingga menunjukan bahwa wanita dan pria pada saat ini memiliki kelebihan dan kekurangan dalam penalaran perilaku etis, tetapi ada juga pria dan wanita bersaing dibidang karir, mencari kekayaan, dan mevari kekuasaan yang mereka inginkan tanpa memikirkan pelanggaran etika.

Kedua, religiositas tidak berpengaruh secara signifikan terhadap perilaku etis akuntan masa depan, kemungkinan banyak faktor yang mempengaruhi antara lain yaitu: pertanyaan yang digunakan tidak sama, data yang digunakan jumlahnya berbeda, waktu penelitian berbeda dan tempat penelitian berbeda. Jika seseorang memiliki religiositas yang rendah, maka untuk melaksanakan tugas bisa saja melakukan kecurangan, sebaliknya jika religiositas seseorang tinggi, maka tugas yang dilakukan kemungkinan bebas dari kecurangan.

Ketiga, kecerdasan intelektual berpengaruh signifikan terhadap perilaku etis akuntan masa depan, sehingga lingkungan pendidikan dapat mempengaruhi sikap dan perilaku etis seseorang.

\section{REFERENSI}

Agoes, Sukrisno and Ardana, I. C. (2013). Etika bisnis dan profesi, tantangan membangun manusia seutuhnya. Journal of Chemical Information and Modeling.

https://doi.org/10.1017/CBO978110741 5324.004

Amirin, M. Tatang. 2010. Skala Likert : "Penggunaan dan Analisis Datanya" http://tatangmayuny.wordpress.com/ Diakses tanggal 15 Agustus 2019.

Asrini, D. (2013). Gender dalam Konteks Teori Struktural-Fungsional dan Teori Sosial Konflik. UNIVERSITAS SURAKARTA.

Aviyah, E., \& Farid, M. (2014). Religiositas, Kontrol Diri dan Kenakalan Remaja. Persona:Jurnal Psikologi Indonesia. https://doi.org/10.30996/persona.v3i02. 376

Azmi,I. N. 2017. Pengaruh Gender, Religiositas, Prestasi Belajar, dan Muatan Etika Dalam Pengajaran Akuntansi Keuangan Terhadap Perilaku Etis Akuntan Masa Depan (Studi Pada Mahasiswa Akuntansi Perguruan Tinggi di Pontianak). Tesis tidak publikasi Oktober 2017

Carr, D., Echols, J. M., \& Shadily, H. (1977). An English-Indonesian Dictionary. Journal of the American Oriental Society. https://doi.org/10.2307/599041

Febrianty. 2010. Pengaruh Gender, Locus of Control, intellectual capital, dan Ethical Sensitivity tehadap Perilaku Etis Mahasiswa Akuntansi Pada Perguruan Tinggi. Jurnal Ilmiah Orasi Bisnis ISSN: 2085-1375 Edisi Ke-IV

Ghozali, I. (2016). Aplikasi Analisis Multivariete IBM SPSS. In Semarang, Universitas Diponegoro. https://doi.org/10.1017/CBO978110741 5324.004

Ifa Hanifah, M. (2008). Antara IQ, EQ, dan SQ. Pelatihan Nasional Guru SeIndonesia.

Ika, D. (2011). Pengaruh kecerdasan emosional dan spiritual terhadap sikap etis mahasiswa akuntansi dipandang dari segi gender (Studi pada Perguruan Tinggi Negeri di Kota Medan). Jurnal Keuangan \& Bisnis.

Junusi, R. El. (2020). COSO-based internal control: efforts towards good university governance. Journal of Islamic 
Accounting and Finance Research, 2(1), 27.

https://doi.org/10.21580/jiafr.2020.2.1. 4773

Muhlis. (2011). Perilaku Menabung di Perbankan Syariah Jawa Tengah. Universitas Dipenogoro.

Pamungkas, I. D. (2014). Pengaruh Religiositas dan Rasionalisasi dalam Mencegah dan Mendeteksi Kecenderungan Kecurangan Akuntansi. Jurnal Ekonomi Dan Bisnis.

Reiss, M. C., dan Mitra, K. 1998. The Effects of Individual Difference Factors on the Acceptability of Ethical and
Unethical Workplace Behaviors. Journal of Business Ethics, Vol. 17. No 12. Pp 1581-1593

Ridha Oktarina. (2017). Pengaruh Gender Terhadap Perilaku Etis Akuntan Di Minangkabau (Studi Eksperimentasi Semu pada Mahasiswa Akuntansi di Kota Padang). Jurnal Akuntansi.

Wardana, A., \& Mimba, N. (2016). Pengaruh Kecerdasan Intelektual, Kecerdasan Emosional, Kecerdasan Spiritual, Dan Gender Pada Sikap Etis Mahasiswa Magister. E-Jurnal Ekonomi Dan Bisnis. 